\title{
Effects of Nitrogen Rates on Cotton under Different Plant Available Water Capacity Sites in Pyawbwe, Central Dry Zone of Myanmar
}

\author{
Thu Zar Win 1*, Aye Aye Than1, Kyaw Ngwe1, Aye Aye Khaing² \\ ${ }^{1}$ Department of Soil and Water Science, Yezin Agricultural University, Naypyitaw, Myanmar \\ ${ }^{2}$ Department of Agronomy, Yezin Agricultural University, Naypyitaw, Myanmar \\ Email: *thuzarwin.pb@gmail.com
}

How to cite this paper: Win, T.Z., Than, A.A., Ngwe, K. and Khaing, A.A. (2021) Effects of Nitrogen Rates on Cotton under Different Plant Available Water Capacity Sites in Pyawbwe, Central Dry Zone of Myanmar. Open Access Library Journal, 8: e7137.

https://doi.org/10.4236/oalib.1107137

Received: January 7, 2021

Accepted: February 23, 2021

Published: February 26, 2021

Copyright $\odot 2021$ by author(s) and Open Access Library Inc.

This work is licensed under the Creative Commons Attribution International License (CC BY 4.0).

http://creativecommons.org/licenses/by/4.0/

(c) (i) Open Access

\begin{abstract}
Soil water content and nutrient availability are two main factors of limiting plant growth and productivity in an uncertain rainfall area likes central dry zone of Myanmar (CDZ). The aim of this research was to observe the effects of nitrogen $(\mathrm{N})$ rates on rainfed cotton (Gossypium hirsutum L.) under different plant available water capacity (PAWC) sites. The field experiments were conducted during post-monsoon season 2019 at two sites, Pawaingyoe and Kokkokhahla, of Pyawbwe Township having different PAWC. In both sites, six levels of $\mathrm{N}$ rate $(\mathrm{T} 1=0, \mathrm{~T} 2=60, \mathrm{~T} 3=90, \mathrm{~T} 4=120, \mathrm{~T} 5=150$ and $\mathrm{T} 6$ $=180 \mathrm{~kg} \mathrm{~N} \mathrm{ha}^{-1}$ ) were laid out in randomized complete block design with four replications and cotton variety Ngwechi- 6 was tested. The effects of $\mathrm{N}$ rates on growth, yield, residual soil $\mathrm{NO}_{3}^{-}-\mathrm{N}$, nitrogen use efficiency (NUE), water use efficiency (WUE) and benefit cost ratio (BCR) were examined. Results showed that PAWC, soil $\mathrm{N}$ and OM levels of the clay loam soil from Pawaingyoe was higher than those of the sandy loam soil from Kokkokhahla. In Pawaingyoe, maximum seed cotton yield $\left(2364 \mathrm{~kg} \mathrm{ha}^{-1}\right)$, NUE, WUE, BCR and lower residual soil $\mathrm{NO}_{3}^{-}-\mathrm{N}$ were achieved by $\mathrm{T} 2\left(60 \mathrm{~kg} \mathrm{~N} \mathrm{ha}^{-1}\right)$. In Kokkokhahla, maximum seed cotton yield (1976 kg ha $\left.{ }^{-1}\right)$, WUE, BCR and higher residual soil $\mathrm{NO}_{3}^{-}-\mathrm{N}$ were found in $\mathrm{T} 4\left(120 \mathrm{~kg} \mathrm{~N} \mathrm{ha}^{-1}\right)$, however, which were followed by $\mathrm{T} 3\left(90 \mathrm{~kg} \mathrm{~N} \mathrm{ha}^{-1}\right)$ with the statistically similar seed cotton yield (1787 $\left.\mathrm{kg} \mathrm{ha}^{-1}\right)$, the maximum NUE and lower residual soil $\mathrm{NO}_{3}^{-}-\mathrm{N}$. Therefore, it may be assumed that $\mathrm{T} 2\left(60 \mathrm{~kg} \mathrm{~N} \mathrm{ha}^{-1}\right)$ was the most suitable rate for Pawaingyoe site while within the range between T3 and T4 (90 to $120 \mathrm{~kg} \mathrm{~N} \mathrm{ha}^{-1}$ ) was appropriate for Kokkokhahla. The finding of this
\end{abstract}


study could be contributed some suggestions to the recommendation for cotton $\mathrm{N}$ rates under similar circumstances.

\section{Subject Areas}

Plant Science

\section{Keywords}

Cotton, Yield, Plant Available Water Capacities, Water Use Efficiency, Nitrogen, Nitrogen Use Efficiency

\section{Introduction}

The Central Dry Zone (CDZ) of Myanmar encompasses three regions, namely the lower Sagaing, Mandalay, and Magway Regions [1] and the majority of the population in CDZ, approximately $83 \%$ is rural residents. Livelihood activities in the $\mathrm{CDZ}$ are dominated by agricultural activities and this zone has low annual rainfall with high variability and uneven distribution [2]. The farmers are generally subsistence small holders with poor knowledge of fertilizer management. The land is undulated, composed mainly of sandy loam with low organic matter content and low fertility. Inherent poor soil fertility, particularly soils low in $\mathrm{N}$ content and micronutrients are major factors and responsible for the low productivity of crop. The crop production in this region is unstable and it depends not only on soil fertility but also on rainfall and availability of soil water.

The soil's ability to support crop growth is largely dependent upon its water-holding and supply capacity, PAWC [3]. Two moisture content levels, drained upper limit (DUL) or field capacity and crop lower limit (CLL) or permanent wilting point, are used to indicate the upper and lower limits of plant available water. Here, DUL is maximum amount of water, soil can hold against the gravity. CLL is the amount of water remaining after a particular crop, has extracted all the water available to it from the soil. DUL is a soil property, CLL depends on both soil and crop, as the depth, distribution and functionality of roots affect water uptake [4]. PAWC is calculated as the difference between soil water content at DUL and soil water content at CLL. Soil characterization for PAWC is required if detailed information on soil water and nutrient availability is needed for a commercial crop, on farm research or simulation [5]. Recently, ACIAR Project (LWR 2014/075) was studied in Pyawbwe Township concerning with "Land resource evaluation for productive and resilient landscapes in the Central Dry Zone of Myanmar" including PAWC.

Cotton (Gossypium hirsutum L.) is one of the important fiber crops grown in the world, which plays an important role in the national economy of Myanmar [6], occupies about 350,000 hectares, primarily in the $\mathrm{CDZ}$ of the country. Among the macronutrients, $\mathrm{N}$ is the most susceptible to losses from soil [7] and the nitrogen use efficiency (NUE) is very low [8]. For cotton production, $\mathrm{N}$ is 
required most consistently and in larger amounts than other nutrients [9]. However, both excess and deficit $\mathrm{N}$ have a detrimental effect on cotton production. Thus, $\mathrm{N}$ fertilization should be done only with the correct amount required by crop, avoiding deficits or excess. The different $\mathrm{N}$ rates: $90,100,120 \mathrm{~kg} \mathrm{ha}^{-1}$ were optimum with three split application (20\% sowing, $40 \%$ at 30 DAS and $40 \%$ at 60 DAS) for rainfed cotton in three different places of Vertisols in India, namely Nagpur, Parbhani and Adilabab, respectively [10]. In the southeastern US the standard cotton $\mathrm{N}$ recommendation rates were 60 to $90 \mathrm{~kg} \mathrm{ha}^{-1}$ for finer texture soils and coastal plain soils [11]. The response of crops to $\mathrm{N}$ fertilizer application is highly dependent on soil water status, amount, and frequency of precipitation during the growing period of crops [12]. In tropical countries such as Myanmar, a deep knowledge of crop $\mathrm{N}$ management based on soil water availability is needed to contribute to obtain optimum yield and reduce the environmental impact. Nowadays, most farmers in Myanmar use high yielding varieties and consequently, it requires more fertilizer application. Although farmers are willing to use more $\mathrm{N}$ fertilizer for a better crop yield, their effort should be more efficient. In addition, the greatest challenge for farmers in CDZ region is to cope with this high level of uncertainty of the weather and the associated availability of soil water. One of the main causes of cotton yield variability in this region is interacting of rainfall with soil water availability and $\mathrm{N}$ supply. Moreover, $\mathrm{N}$ fertilizer responses in relation with PAWC have not been studied in Myanmar. Therefore, this study was conducted to observe the effects of $\mathrm{N}$ rates on rainfed cotton under different PAWC sites.

\section{Materials and Methods}

\subsection{Site Description}

This study was conducted at the two villages Pawaingyoe and Kokkokhahla of Pyawbwe Township in Mandalay Region, CDZ of Myanmar (Figure 1) during 2019 post-monsoon season. Pyawbwe is located at latitude $20.5977^{\circ} \mathrm{N}$, longitude

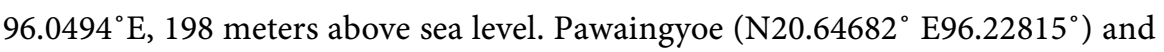
Kokkokhahla (N20.55128 ${ }^{\circ}$ E95.96853 ${ }^{\circ}$ ) are located in eastern and southern parts of Pyawbwe, respectively.

\subsection{Experimental Design and Field Management}

In both experimental sites Pawaingyoe and Kokkokhahla, following mung bean the cotton cultivar Ngwechi- 6 was sown with the spacing $0.75 \mathrm{~m} \times 0.75 \mathrm{~m}$, on 27 July 2019 and on 4 August 2019 respectively. The experimental plots were laid out in randomized complete block (RCB) design with four replications. The experimental fields contained 24 plots with the size of $45.56 \mathrm{~m}^{2}$ including 9 rows and 9 hills in each row. The experimental design, used cultivar, plot size, treatments, all field management practices, data collections and data calculations were the same for both sites. Six levels of $\mathrm{N}$ rate source as urea $(\mathrm{T} 1=0, \mathrm{~T} 2=60$, $\mathrm{T} 3=90, \mathrm{~T} 4=120, \mathrm{~T} 5=150$ and $\mathrm{T} 6=180 \mathrm{~kg} \mathrm{~N} \mathrm{ha}^{-1}$ ) were used as treatments. 


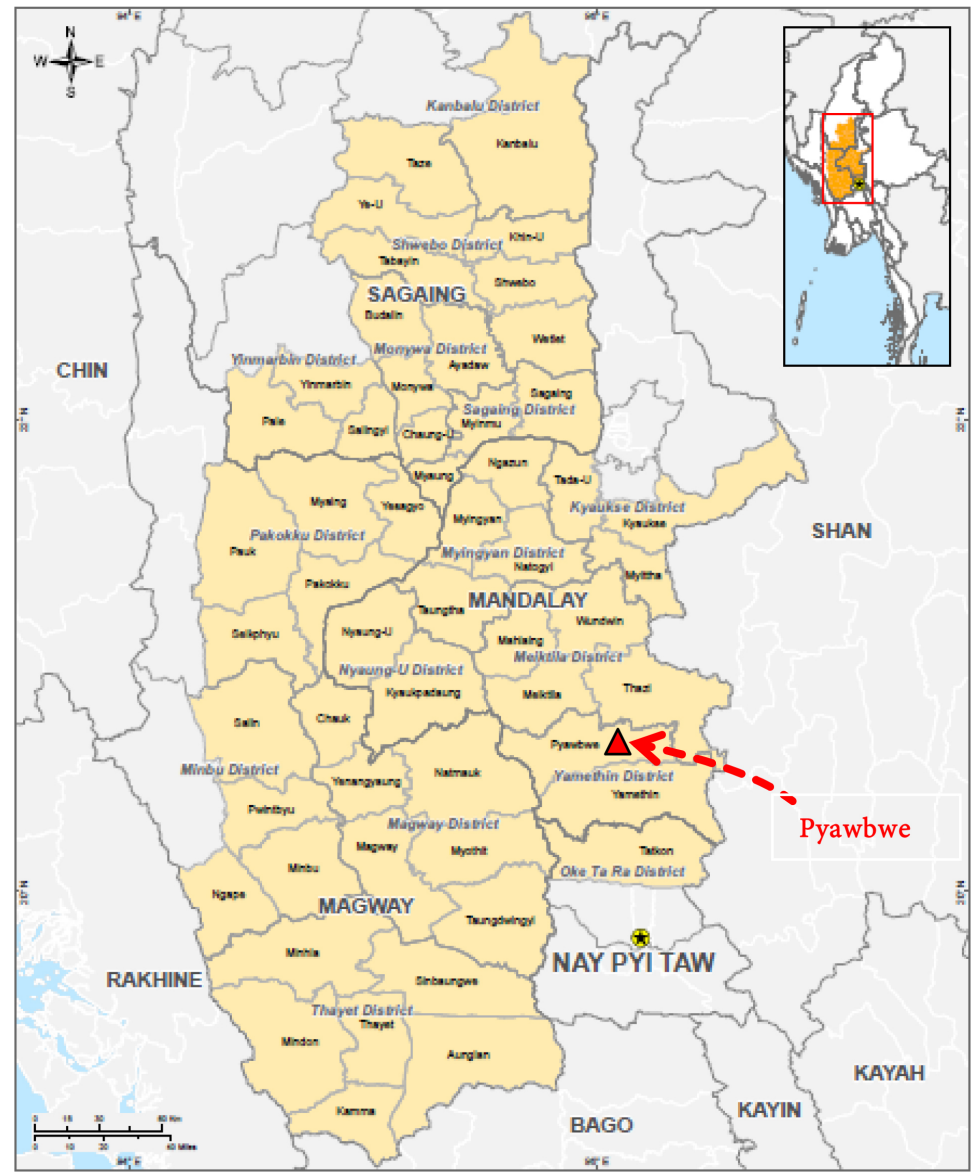

(a)

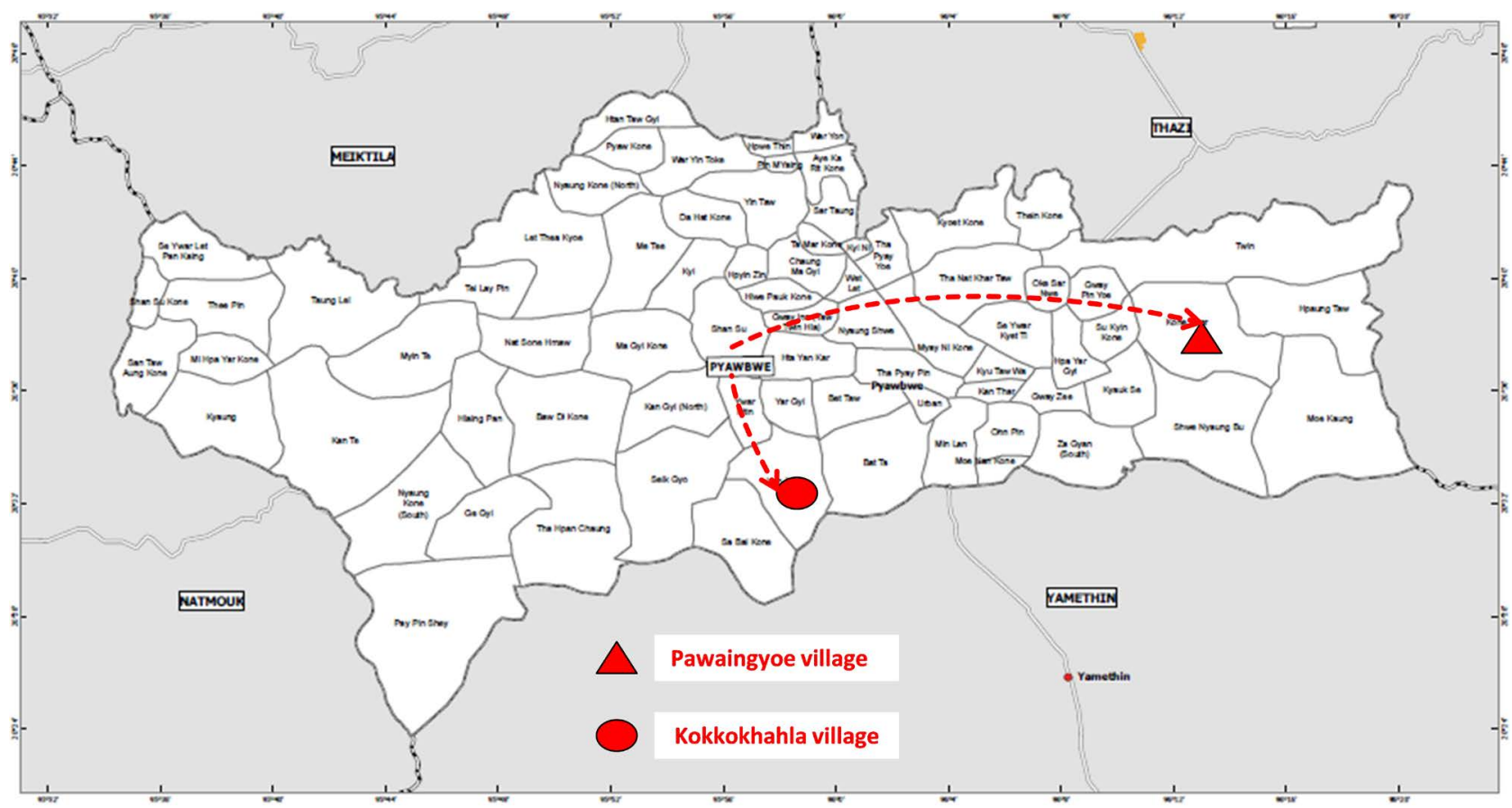

(b)

Figure 1. (a) CDZ of Myanmar, Source: [13] (a); (b) Location of study area; Pawaingyoe and Kokkokhahla villages in Pyawbwe Township, Source: [13] (b). 
$\mathrm{N}$ was applied as split dose, i.e., $20 \%$ at sowing, $40 \%$ at squaring, $40 \%$ at flowering. For all treatments triple super phosphate $\left(60 \mathrm{~kg} \mathrm{P}_{2} \mathrm{O}_{5} \mathrm{ha}^{-1}\right)$, muriate of potash $\left(60 \mathrm{~kg} \mathrm{~K}_{2} \mathrm{O} \mathrm{ha}{ }^{-1}\right)$, zinc sulphate $\left(15 \mathrm{~kg} \mathrm{ha}^{-1}\right)$ and borax $\left(5 \mathrm{~kg} \mathrm{ha}^{-1}\right)$ were applied at basal. Cotton seeds were treated with dozar $20 \%$ WP $0.25 \mathrm{~kg} \mathrm{ha}^{-1}$ to prevent from sucking pests at the seedling stage and field managements were implemented as the usual cultural practices. Pest control and other management practices were conducted as necessary. Management was the same across all treatments in each experimental site.

\subsection{Soil Sampling}

The representative soil samples of the two experimental sites were randomly collected as composite samples by classing the layers $(0$ - 10, 10 - 20, 20 - 30, 30 50, $50-70,70-100$ and $100-150 \mathrm{~cm}$ ) using a soil auger. Total N, available N, P, $\mathrm{K}$ were analyzed from the plough layer $(0-20 \mathrm{~cm})$ and soil texture, $\mathrm{pH}, \mathrm{EC}$, ECEC, $\mathrm{NO}_{3}^{-}-\mathrm{N}$ and organic carbon were analyzed from each soil layer. Soil analysis was done at Laboratory in Department of Soil and Water Science of Yezin Agricultural University, and Laboratory in Soil Science Section of Department of Agricultural Research. Some soil data were obtained from ACIAR Project (LWR 2014/075).

\subsection{Sampling for Bulk Density (BD), DUL and CLL}

To measure DUL the soil needs to be wetted up, and then left to drain naturally without any moisture escaping by transpiration or evaporation. When the soil received sufficient rainfall, all vegetation of the selected area was cleaned and tarpaulins were placed over the site to seal and trap soil moisture. Weeds and other vegetation that surrounds the tarpaulin were removed to prevent them from using trapped water. When the soil has drained naturally and is stable, DUL was measured on 10 October 2019 for both sites and soil samples were collected to determine the gravimetric water content of the soil layers. A soil pit was excavated to $1.5 \mathrm{~m}$ depth. The sample intervals were 0 - 10, $10-20,20-30,30$ $50,50-70,70-100$ and $100-150 \mathrm{~cm}$. The sample were taken 3 replicates $\times 7$ layers per site by using core ring which has $5 \mathrm{~cm}$ height and $2.5 \mathrm{~cm}$ radius. Since, the samples taken were a known volume and thus BD of the soil can be determined. The fresh weights of samples (+jar) were measured in the field. Then, the samples were dried in an oven at $105^{\circ} \mathrm{C}$ until getting constant weight. CLL were measured at crop maturity. CLL samples were collected near the DUL site. For the surface layers, dig a small pit and fill the jar with soil from the relevant layer. For deeper layers, an auger was used to obtain the sample making sure that the sample was from the correct interval. The depth intervals were the same as those used for DUL sampling. The following formulae were used in defining PAWC and its associated variables [5].

$$
\text { Gravimetric water }=\frac{(\text { wet weight of sample }- \text { dry weight of sample })}{\text { dry weight of sample }}
$$




$$
\begin{aligned}
& \text { Gravimetric water } \%=\frac{(\text { wet weight of sample }- \text { dry weight of sample })}{\text { dry weight of sample }} \times 100 \\
& \text { Bulk density }\left(\mathrm{g} / \mathrm{cm}^{3}\right)=\text { dry soil weight }(\mathrm{g}) / \text { total volume of soil }\left(\mathrm{cm}^{3}\right) \\
& \text { Core ring volume }\left(\mathrm{cm}^{3}\right)=\text { height } \times \text { radius }{ }^{2} \times \pi \\
& \text { DUL }(\text { volumetric water } \%)=\text { Gravimetric water } \% \times \text { soil bulk density } \\
& \text { CLL }(\text { volumetric water } \%)=\text { Gravimetric water } \% \times \text { soil bulk density } \\
& \text { PAWC }(\mathrm{mm}) \text { for } 1 \text { depth interval }=[\text { DUL }-\mathrm{CLL}] \times[\text { depth interval }(\mathrm{cm}) / 10]
\end{aligned}
$$

\subsection{Periodic Monitoring of Soil Water}

Soil water contents were gravimetrically measured at planting time and at 15 days intervals throughout the growing season to a depth of $150 \mathrm{~cm}$. The sample intervals were $0-10,10-20,20-30,30-50,50-70,70-100$ and $100-150 \mathrm{~cm}$. The fresh weights of samples (+jar) were measured in the field, and then dried in an oven at $105^{\circ} \mathrm{C}$ to a constant weight to determine gravimetric soil water content that was then converted to volumetric water content according to the soil bulk density.

\subsection{Residual Soil $\mathrm{NO}_{3}^{-}-\mathrm{N}$ Content after Harvesting Cotton}

During the dry season after harvesting cotton, soil samples were taken from 0 10, 10 - 20, 20 - 30, 30 - 50, $50-70,70-100$ and $100-150 \mathrm{~cm}$ soil layers of each experimental plot and soil $\mathrm{NO}_{3}^{-}-\mathrm{N}$ contents were immediately analyzed with Ion selective electrode.

\subsection{Crop Measurements}

Ten plants in the central three rows per plot were randomly tagged to determine plant height, number of monopodial branches, sympodial branches, main stem nodes, yield and yield components. Plant height was taken as the distance between terminal bud and cotyledon nodes and measured at 15 days interval for six times starting from 30 DAS (day after sowing). Number of monopodial branches, sympodial branches and main stem nodes were counted at harvest time. Yield components data such as number of boll plant ${ }^{-1}$, individual boll weight (grams of seed cotton boll-1), 1000 seed weight and boll weight plant ${ }^{-1}$ were recorded at harvest time. Four times hand picking were done and total seed cotton yield of each plot (including 10 plant subsamples) in the central three rows was weighed after sun dried and then this yield was calculated into yield per hectare. The data obtained from this test were statistically analyzed with Statistix 8 software and the treatment means were done using Least Significant Difference (LSD) test at $5 \%$ level of significance.

\subsection{Water Use Efficiency (WUE $\mathrm{kg} \mathrm{ha}^{-1} \mathrm{~mm}^{-1}$ )}

Water use efficiency (WUE) can be defined in different ways and in this experi- 
ment, the agronomic or crop WUE has been used and it was calculated according to [14].

$$
\operatorname{WUE}\left(\mathrm{kg} \mathrm{ha}^{-1} \mathrm{~mm}^{-1}\right)=\frac{e}{f-g+h}
$$

where, $e=$ crop yield or above ground biomass yield $\left(\mathrm{kg} \mathrm{ha}^{-1}\right), f=$ soil water contents $(\mathrm{mm})$ measured at sowing time, $g=$ soil water contents $(\mathrm{mm})$ measured at harvest time, $h=$ rainfall during the crop growing season $(\mathrm{mm})$.

\subsection{Agronomic Nitrogen Use Efficiency (NUE)}

The agronomic NUE refers to an increase in seed cotton yield $\left(\mathrm{kg} \mathrm{ha}^{-1}\right)$ per unit of $\mathrm{N}$ applied [15].

$$
\text { Agronomic NUE }=\frac{\text { Yield }_{\mathrm{f}}-\text { Yield }_{0}}{\mathrm{~N} \text { apply }}
$$

where, Yield $_{\mathrm{f}}=$ seed cotton yield in a treatment with $\mathrm{N}$ application $\left(\mathrm{kg} \mathrm{ha}^{-1}\right)$, Yield $_{0}=$ seed cotton yield in a treatment without $\mathrm{N}$ application $\left(\mathrm{kg} \mathrm{ha}^{-1}\right), \mathrm{N}=$ the amount of fertilizer $\mathrm{N}$ applied $\left(\mathrm{kg} \mathrm{ha}^{-1}\right)$.

\subsection{Benefit Cost Ratio (BCR)}

To compare the profit of treatments used, the simple economic analyses was done. Benefit cost ratio was computed for each treatment considering the cost of fertilizer and gross return from seed cotton yield using the following equation:

$$
\text { Benefit Cost Ratio }(\mathrm{BCR})=\frac{\text { Gross return }(\mathrm{Ti})-\mathrm{Gross} \text { return }(\mathrm{T} 1)}{\mathrm{FC}(\mathrm{Ti})-\mathrm{FC}(\mathrm{T} 1)}
$$

where, $\mathrm{Ti}=\mathrm{T} 2, \mathrm{~T} 3, \ldots, \mathrm{T} 6$ Treatments, $\mathrm{T} 1=$ Control treatment, $\mathrm{FC}=$ Fertilizer cost.

\section{Results and Discussion}

\subsection{Soil Physicochemical Properties before Planting}

Table 1 and Table 2 show soil analysis data of Pawaingyoe and Kokkokhahla. Pawaingyoe soil has more total $\mathrm{N}$ than Kokkokhahla, low levels of available N, P and medium amount of available K. Kokkokhahla soil has very low level of available $\mathrm{N}$, medium level of available $\mathrm{P}$ and high level of available $\mathrm{K}$. The physicochemical properties from different soil layers of the soil varied among the two sites. Pawaingyoe was characterized by clay loam texture and Kokkokhahla was characterized by sandy loam. Pawaingyoe soil has more ECEC, OC and $\mathrm{NO}_{3}^{-}-\mathrm{N}$ values than Kokkokhahla. For both sites, the $\mathrm{pH}$ values generally increased with soil depth, and fell within slightly acid to neutral. EC values showed no salinity problem in all soil layers.

\subsection{Weather Condition}

The amounts of total rainfall during the growing season (August-December) of 
the experimental period 2019 were $387 \mathrm{~mm}$ and $515 \mathrm{~mm}$ in Pawaingyoe and Kokkokhahla respectively, which were $4.59 \%$ and $5.97 \%$ higher than ten years average (2009-2018) growing season rainfall $370 \mathrm{~mm}$ in Pawaingyoe and 486 $\mathrm{mm}$ in Kokkokhahla (Figure 2). The growing season rainfall in Kokkokhahla was $33.07 \%$ higher than Pawaingyoe. However, the minimum and maximum temperatures ranges during 2019 and 10 years average (2009-2018) were similar between $16^{\circ} \mathrm{C}$ to $23^{\circ} \mathrm{C}$ and $30^{\circ} \mathrm{C}$ to $35^{\circ} \mathrm{C}$ in Pawaingyoe, and $16^{\circ} \mathrm{C}$ to $25^{\circ} \mathrm{C}$ and $31^{\circ} \mathrm{C}$ to $35^{\circ} \mathrm{C}$ in Kokkokhahla.

Table 1. Some soil properties of Pawaingyoe and Kokkokhahla (from $0-20 \mathrm{~cm}$ depth).

\begin{tabular}{|c|c|c|c|}
\hline \multirow{2}{*}{ Parameters } & \multicolumn{2}{|c|}{ Analytical results } & \multirow{2}{*}{ Analytical Method } \\
\hline & Pawaingyoe & Kokkokhahla & \\
\hline Total N (\%) & $0.05 \%$ (low) & $0.01 \%$ (very low) & Kjaldehl distillation method \\
\hline Available $\mathrm{N}\left(\mathrm{mg} \cdot \mathrm{kg}^{-1}\right)$ & 47 (low) & 29 (very low) & Alkaline permanganate method \\
\hline Available $\mathrm{P}\left(\mathrm{mg} \cdot \mathrm{kg}^{-1}\right)$ & 9.3 (low) & 19.7 (medium) & 9C-Olsen's P-Malachite green \\
\hline Available $\mathrm{K}\left(\mathrm{mg} \cdot \mathrm{kg}^{-1}\right)$ & 170 (medium) & 300 (high) & 15A1-1N Ammonium acetate extraction \\
\hline
\end{tabular}

Table 2. Physicochemical properties of different soil layers of Pawaingyoe and Kokkokhahla before planting.

\begin{tabular}{|c|c|c|c|c|c|c|c|c|c|c|}
\hline Sites & $\begin{array}{l}\text { Soil depth } \\
(\mathrm{cm})\end{array}$ & $\begin{array}{c}\mathrm{pH} \\
\text { (1:5 soil:water) }\end{array}$ & $\begin{array}{c}\text { EC } \\
(\mathrm{d} S / \mathrm{m}) \\
(1: 5 \text { soil:water })\end{array}$ & $\begin{array}{c}\text { ECEC } \\
\mathrm{cmol}(+) \mathrm{kg}^{-1}\end{array}$ & $\begin{array}{c}\text { OC } \\
\%\end{array}$ & $\begin{array}{l}\mathrm{NO}_{3}^{-}-\mathrm{N} \\
\mathrm{mg} \cdot \mathrm{kg}^{-1}\end{array}$ & $\begin{array}{c}\text { Sand } \\
\%\end{array}$ & $\begin{array}{l}\text { Silt } \\
\%\end{array}$ & $\begin{array}{c}\text { Clay } \\
\%\end{array}$ & Texture \\
\hline \multirow{7}{*}{ Pawaingyoe } & $0-10$ & 6.76 & 0.07 & 8.43 & 1.10 & 4.06 & 39.00 & 37.40 & 23.60 & Loam \\
\hline & $10-20$ & 6.44 & 0.06 & 7.67 & 1.04 & 4.19 & 42.00 & 36.70 & 21.30 & Loam \\
\hline & $20-30$ & 6.36 & 0.04 & 11.26 & 1.02 & 3.92 & 30.20 & 38.60 & 31.20 & Clay loam \\
\hline & $30-50$ & 6.72 & 0.05 & 10.35 & 1.82 & 3.51 & 33.70 & 34.50 & 31.80 & Clay loam \\
\hline & $50-70$ & 6.91 & 0.07 & 10.12 & 0.72 & 2.52 & 37.50 & 32.50 & 30.00 & Clay loam \\
\hline & $70-100$ & 7.22 & 0.04 & 13.30 & 0.57 & 2.29 & 26.20 & 38.40 & 35.40 & Clay loam \\
\hline & $100-150$ & 7.34 & 0.08 & 20.00 & 1.10 & 3.60 & 35.00 & 34.00 & 31.00 & Clay loam \\
\hline \multirow{7}{*}{ Kokkokhahla } & $0-10$ & 6.45 & 0.07 & 8.53 & 0.44 & 1.68 & 72.20 & 21.90 & 5.90 & Sandy loam \\
\hline & $10-20$ & 6.64 & 0.30 & 4.56 & 0.34 & 1.51 & 72.90 & 19.60 & 7.50 & Sandy loam \\
\hline & $20-30$ & 6.59 & 0.05 & 9.35 & 0.34 & 1.26 & 66.10 & 23.80 & 10.10 & Sandy loam \\
\hline & $30-50$ & 6.44 & 0.09 & 11.27 & 0.27 & 0.92 & 65.40 & 18.20 & 16.40 & Sandy loam \\
\hline & $50-70$ & 6.69 & 0.06 & 7.64 & 0.11 & 1.01 & 66.80 & 19.40 & 13.80 & Sandy loam \\
\hline & $70-100$ & 6.74 & 0.07 & 8.96 & 0.06 & 1.06 & 66.40 & 19.90 & 13.70 & Sandy loam \\
\hline & $100-150$ & 7.12 & 0.09 & 7.00 & 0.09 & 0.99 & 82.00 & 8.00 & 10.00 & Loamy sand \\
\hline
\end{tabular}



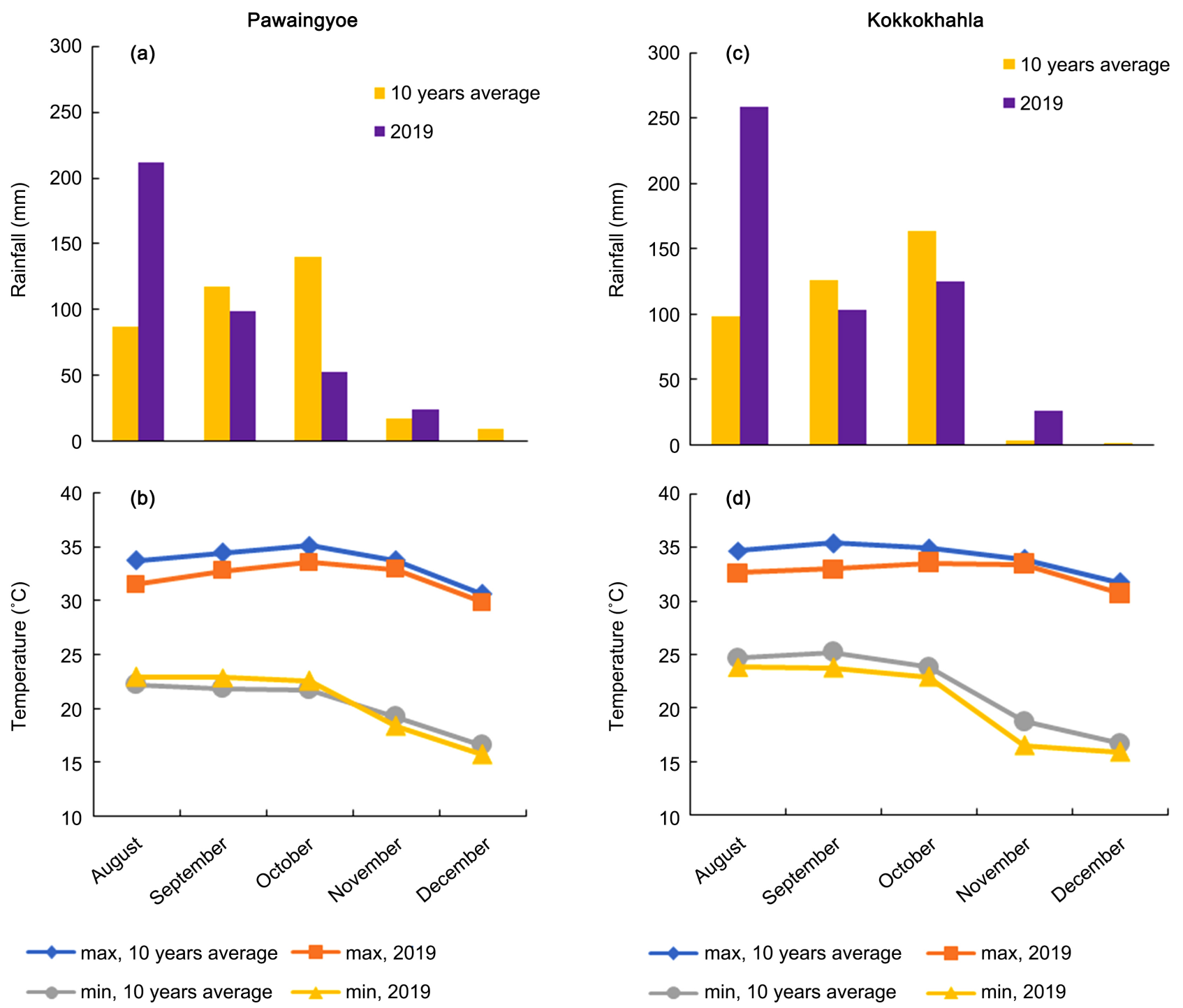

Figure 2. Weather data for 10 years average and 2019: (a) rainfalls; (b) temperature of Pawaingyoe; and (c) rainfall; (d) temperature of Kokkokhahla.

\subsection{DUL, CLL, PAWC and BD}

The values of DUL, CLL, PAWC and BD for both sites were shown in Figure 3. According to the results, Pawaingyoe (clay loam) had higher amount of DUL, CLL, PAWC value and lower amount of BD than Kokkokhahla (sandy loam) in all soil depth. Total PAWC (up to depth, $150 \mathrm{~cm}$ ) of these soils were $250.78 \mathrm{~mm}$ in Pawaingyoe and $150.84 \mathrm{~mm}$ in Kokkokhahla. Such differences in soil water content within the soil profile caused mainly due to variations in soil texture rather than rainfall.

Owing to the association between clay content and soil porosity, soils with higher clay content have greater soil water storage capacity than sandy soils. Soil texture affects the water content and drainage ability of soils [16]. Another reason may be due to the effect of organic matter. Since, Kokkokhahla soil had lower OC \% than Pawaingyoe. 


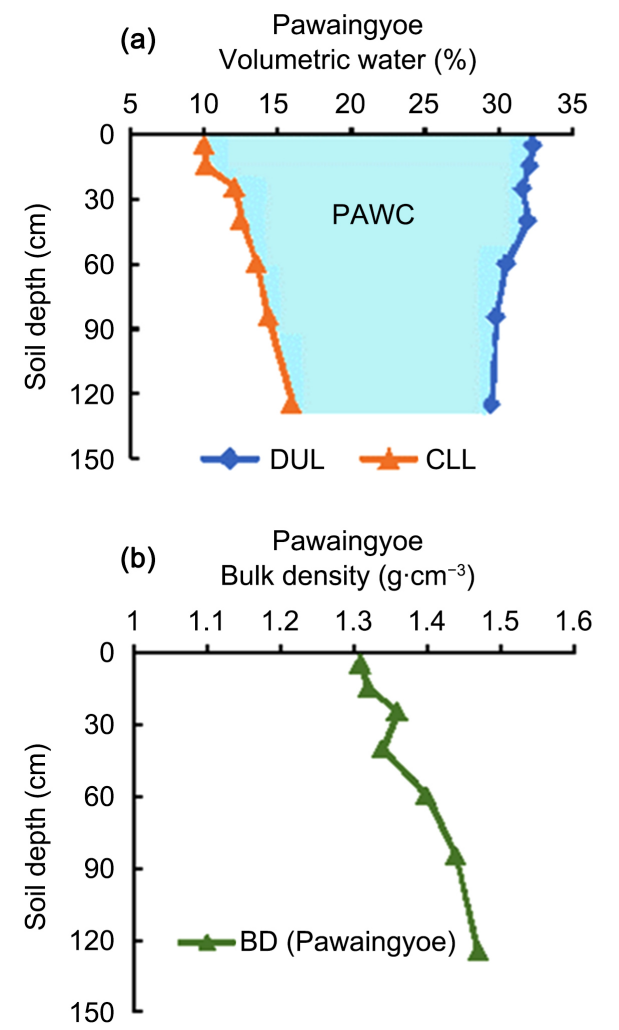

(c) Kokkokhahla

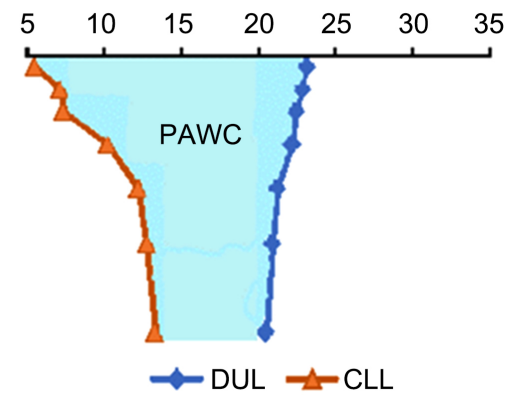

(d) Kokkokhahla

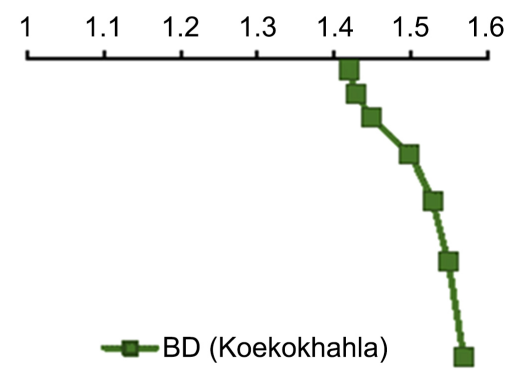

Figure 3. Parameters for PAWC: (a) DUL, CLL, and PAWC; (b) BD of Pawaingyoe; and (c) DUL, CLL, and PAWC; (d) BD of Kokkokhahla.

PAWC is positively related to soil organic matter. Soil organic matter enhances soil water retention because of its hydrophilic nature and its positive influence on soil aggregate formation. It has been recognized that decreases in soil OC could reduce PAWC and soil fertility [17].

\subsection{Periodic Soil Water Status}

Soil water content gravimetrically measured at planting time and at 15 days intervals are shown in Figure 4. Although growing season rainfall in Kokkokhahla was higher than Pawaingyoe, soil water content of Pawaingyoe was higher than Kokkokhahla for all sampling period. This implied PAWC, and hence Pawaingyoe had higher PAWC than Kokkokhahla. The availability of soil water was affected by rainfall event occurred during the cropping season and PAWC of the soil.

In Pawaingyoe, soil water content was low at sowing time. After that period, it slightly increased at 15 DAS and drastically increased during 30 to 45 DAS and the highest soil water content was found at 45 DAS followed by 60 and 30 DAS (Figure 4). The soil water content at 45 DAS was higher than that of DUL because this time was closed to rainy day and the soil water might be at saturated condition. After this period, the moisture content was in decreasing trend. The lowest soil moisture was observed at 105 DAS but it was higher than that of CLL. This may be due to the high rainfall during early growth stage and very low rainfall during October (53 $\mathrm{mm}$ ) and November (24 mm) (Figure 2). 

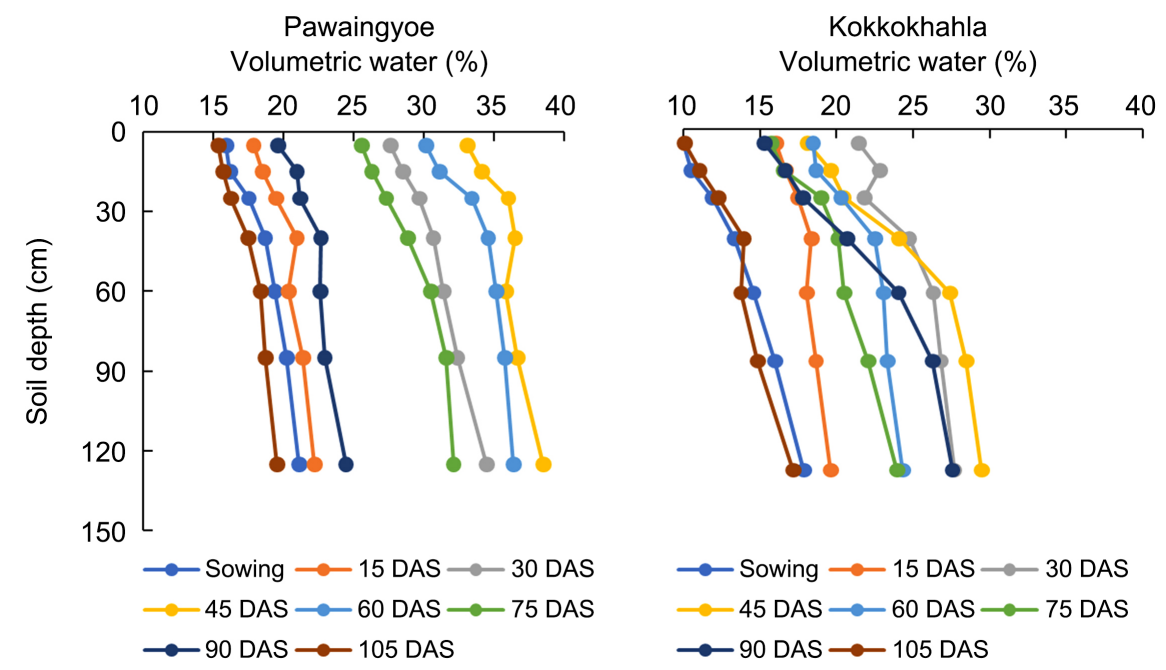

Figure 4. The periodic soil water content of different soil depth $(0-150 \mathrm{~cm})$ during the growing season in Pawaingyoe and Kokkokhahla.

In Kokkokhahla, the low soil water content was observed at sowing time and after that period it increased during 15 and 30 DAS. The soil water content was high at 30, 45 and 60 DAS, and this was due to the highest rainfall during August $(259 \mathrm{~mm})$ and September $(104 \mathrm{~mm})$ (Figure 2). The lowest water content at 105 DAS may be because of the low rainfall event during October $(126 \mathrm{~mm})$ and November $(26 \mathrm{~mm})$, however, this amount of water content was higher than that of CLL.

\subsection{Soil $\mathrm{NO}_{3}^{-}-\mathrm{N}$ Content after Harvesting Cotton}

The result showed that residual $\mathrm{NO}_{3}^{-}-\mathrm{N}$ content was relatively low in both sites (Figure 5). However, this amount was increased than before planting (Table 2) and a large part of this may be derived from $\mathrm{N}$ fertilizer that was applied to the field, besides from the mineralization of organic N. Generally, soil $\mathrm{NO}_{3}^{-}-\mathrm{N}$ concentration of Pawaingyoe (clay loam, higher OC\%) was higher than Kokkokhahla (sandy loam, lower OC\%). Pawaingyoe showed higher residual $\mathrm{NO}_{3}^{-}-\mathrm{N}$ in near surface depth increments while Kokkokhahla showed higher $\mathrm{NO}_{3}^{-}-\mathrm{N}$ levels at deeper depth increments. According to [18], fine textured soils exhibit less nitrate leaching than coarse textured soils.

In Kokkokhahla, higher nitrate- $\mathrm{N}$ accumulation in all $\mathrm{N}$ treatments were found in deeper soil layers $(50-150 \mathrm{~cm}$ ) (Figure 5), this may be attributed to leaching of nitrate along with urea input, because of poor water holding capacity of this soil. Soil characteristics play role in the leaching rate, as soils differ greatly in the extent and manner in which they transmit water [19]. Table 3 shows the influences of $\mathrm{N}$ rates on total residual soil $\mathrm{NO}_{3}^{-}-\mathrm{N}$ accumulation level in the whole profile $0-150 \mathrm{~cm}$ and the calculation was done according to [20]. In Pawaingyoe, the amount of residual soil $\mathrm{NO}_{3}^{-}-\mathrm{N}$ in $\mathrm{T} 2$ is relatively lower than $\mathrm{T} 3$, T4, T5, and T6. In Kokkokhahla, T4, T5, and T6 had the similar amounts, which were substantially higher than $\mathrm{T} 3$ in terms of residual soil $\mathrm{NO}_{3}^{-}-\mathrm{N}$. 


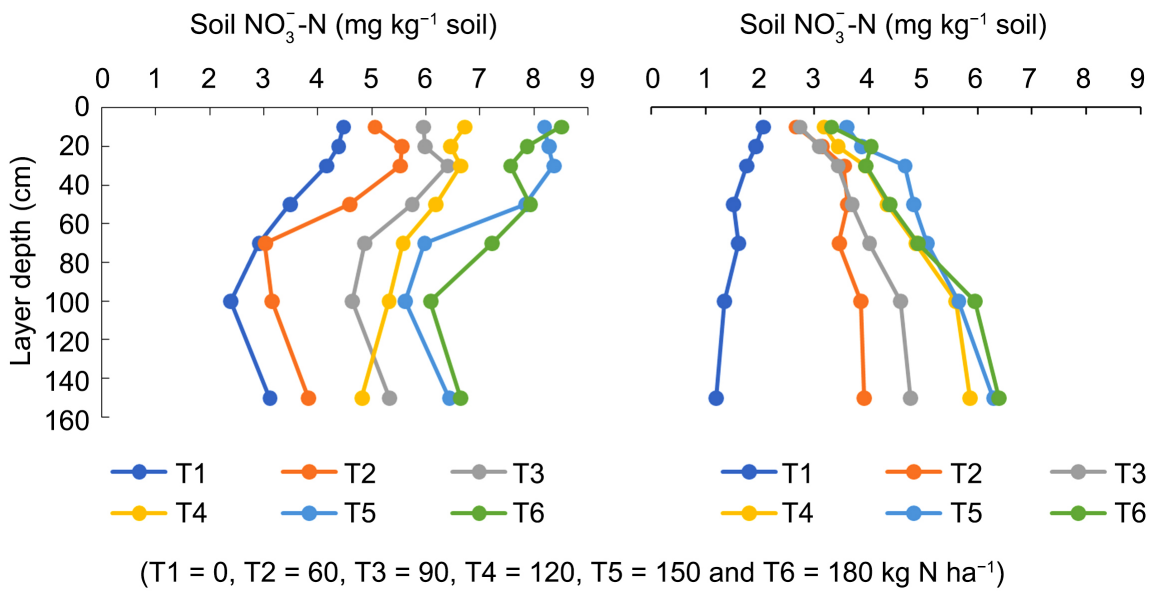

Figure 5. Distribution of residual soil $\mathrm{NO}_{3}^{-}-\mathrm{N}$ in different soil depth after harvesting cotton in Pawaingyoe and Kokkokhahla.

Table 3. Influence of $\mathrm{N}$ rates on residual soil $\mathrm{NO}_{3}^{-}-\mathrm{N}$ level in $0-150 \mathrm{~cm}$ profile.

\begin{tabular}{|c|c|c|}
\hline \multirow{2}{*}{ Treatments } & \multicolumn{2}{|c|}{ Residual soil $\mathrm{NO}_{3}^{-}-\mathrm{N} \quad\left(\mathrm{kg} \mathrm{ha}^{-1}\right)$} \\
\hline & Pawaingyoe & Kokkokhahla \\
\hline $\mathrm{T} 1\left(0 \mathrm{~kg} \mathrm{~N} \mathrm{ha}^{-1}\right)$ & 53.21 & 22.85 \\
\hline $\mathrm{T} 2\left(60 \mathrm{~kg} \mathrm{~N} \mathrm{ha}^{-1}\right)$ & 65.59 & 62.16 \\
\hline T3 $\left(90 \mathrm{~kg} \mathrm{~N} \mathrm{ha}^{-1}\right)$ & 88.86 & 72.54 \\
\hline $\mathrm{T} 4\left(120 \mathrm{~kg} \mathrm{~N} \mathrm{ha}^{-1}\right)$ & 88.44 & 88.16 \\
\hline T5 $\left(150 \mathrm{~kg} \mathrm{~N} \mathrm{ha}^{-1}\right)$ & 110.89 & 94.45 \\
\hline T6 $\left(180 \mathrm{~kg} \mathrm{~N} \mathrm{ha}^{-1}\right)$ & 115.20 & 94.53 \\
\hline
\end{tabular}

\subsection{Plant Growth Characters}

Plant height of cotton as influenced by various $\mathrm{N}$ rates in Pawaingyoe and Kokkokhahla are shown in Figure 6 and Table 4.

The results indicate that plant height was significantly affected by different $\mathrm{N}$ treatments in both sites for all sampling time, except 30 DAS. At 105 DAS, the highest plant height in Pawaingyoe was observed in T3 $(121.33 \mathrm{~cm})$ and the lowest plant height was found in T1 $(83.57 \mathrm{~cm})$. Plant height of T2, T4 and T5 were not significantly different from each other (Table 4). In Kokkokhahla, the highest plant height was observed in T5 $(106 \mathrm{~cm})$ but it was not statistically different from T4 $(103.53 \mathrm{~cm})$ and $\mathrm{T} 6(101.32 \mathrm{~cm})$. The lowest plant height was found in T1 $(72.13 \mathrm{~cm})$. The number of main-stem node plant $^{-1}$ and the number of monopodial branches plant ${ }^{-1}$ were not significantly different among the treatments in both sites (Table 4). $\mathrm{N}$ fertilization increased significantly the number of sympodial branches plant ${ }^{-1}$ over control treatment (T1) in both sites. The sympodial branch is one of the important parameters which directly affect 
the cotton yield and it is assumed in many literatures as the fruiting branches. In Pawaingyoe, T2 gave the maximum number of sympodial branches plant ${ }^{-1}$ (16.09) and it was not significantly different among other higher $\mathrm{N}$ rate treatments. This highlighted that increase $\mathrm{N}$ dosage more than $\mathrm{T} 2\left(60 \mathrm{~kg} \mathrm{~N} \mathrm{ha}^{-1}\right)$ did not increase sympodial branches for this site. In Kokkokhahla, T4 gave the highest number of sympodial branches plant ${ }^{-1}$ followed by T6, T5 and T3; the lowest was obtained from $\mathrm{T} 1$ treatment. The increase in number of sympodial branches with increasing $\mathrm{N}$ application rate has also been reported by [21].

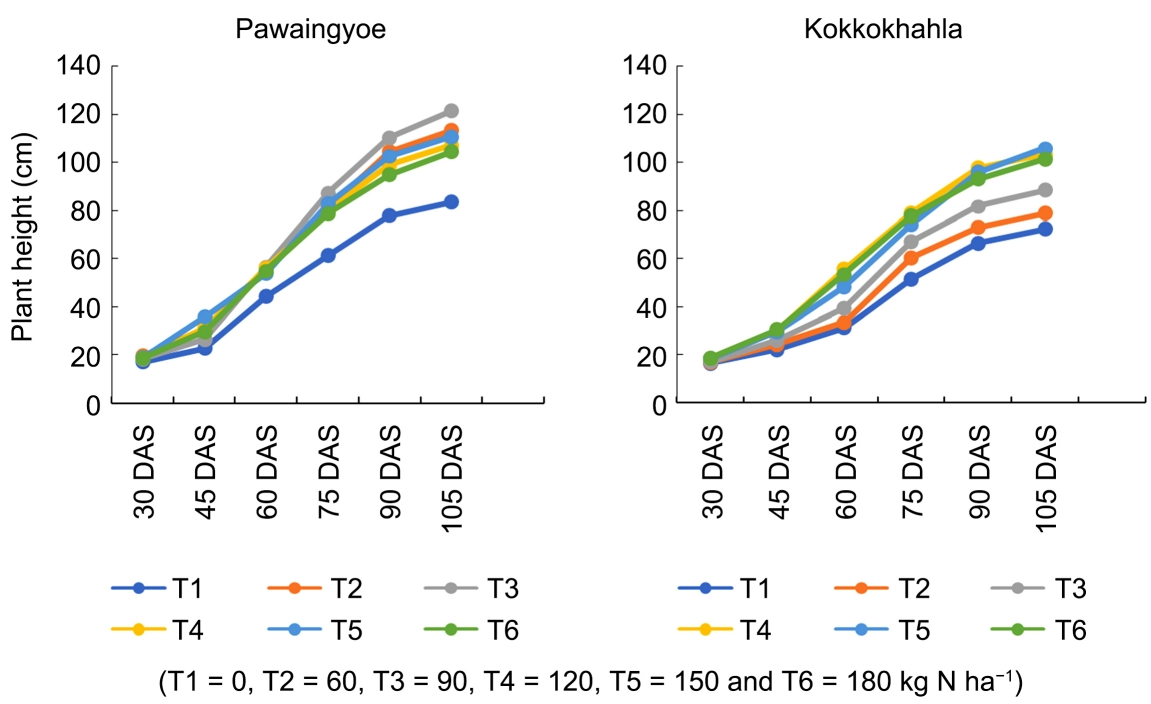

Figure 6. Effect of $\mathrm{N}$ fertilization on plant height of cotton at different sampling time in Pawaingyoe and Kokkokhahla.

Table 4. Mean comparison of plant growth characters of cotton as affected by nitrogen fertilization in Pawaingyoe and Kokkokhahla.

\begin{tabular}{|c|c|c|c|c|c|c|c|c|}
\hline \multirow{2}{*}{ Treatments } & \multicolumn{2}{|c|}{ Plant height $(\mathrm{cm})$} & \multicolumn{2}{|c|}{$\begin{array}{l}\text { No. of main-stem nodes } \\
\text { plant }^{-1}\end{array}$} & \multicolumn{2}{|c|}{$\begin{array}{l}\text { No. of monopodial branches } \\
\text { plant }^{-1}\end{array}$} & \multicolumn{2}{|c|}{$\begin{array}{l}\text { No. of sympodial branches } \\
\text { plant }^{-1}\end{array}$} \\
\hline & Pawaingyoe & Kokkokhahla & Pawaingyoe & Kokkokhahla & Pawaingyoe & Kokkokhahla & Pawaingyoe & Kokkokhahla \\
\hline $\mathrm{T} 1$ & $83.57 c$ & $72.13 c$ & 20.65 & 19.98 & 1.92 & 1.98 & $12.10 \mathrm{~b}$ & $11.08 \mathrm{c}$ \\
\hline $\mathrm{T} 2$ & $113.25 \mathrm{ab}$ & $78.85 \mathrm{bc}$ & 24.04 & 22.53 & 2.00 & 1.97 & $16.09 \mathrm{a}$ & $12.86 \mathrm{bc}$ \\
\hline T3 & $121.33 \mathrm{a}$ & $88.45 b$ & 24.05 & 22.73 & 2.18 & 2.03 & $15.40 \mathrm{a}$ & $13.98 \mathrm{ab}$ \\
\hline $\mathrm{T} 4$ & $107.05 \mathrm{ab}$ & $103.53 a$ & 23.83 & 24.08 & 2.15 & 2.05 & $15.67 \mathrm{a}$ & $15.93 a$ \\
\hline T5 & $110.65 \mathrm{ab}$ & $106.00 \mathrm{a}$ & 23.05 & 23.69 & 2.08 & 2.15 & $14.81 \mathrm{a}$ & $15.20 \mathrm{ab}$ \\
\hline T6 & $104.30 \mathrm{~b}$ & $101.32 \mathrm{a}$ & 22.23 & 23.10 & 2.05 & 2.08 & $15.09 \mathrm{a}$ & $15.40 \mathrm{ab}$ \\
\hline $\mathrm{LSD}_{0.05}$ & 14.29 & 12.54 & 3.84 & 4.05 & 0.22 & 0.23 & 2.113 & 2.69 \\
\hline $\operatorname{Pr}>F$ & $* *$ & ** & ns & ns & ns & ns & * & * \\
\hline CV\% & 8.89 & 9.07 & 11.09 & 11.86 & 7.1 & 7.61 & 9.35 & 12.67 \\
\hline
\end{tabular}




\subsection{Yield and Yield Components}

There were significant differences in seed cotton yield and all yield components of both sites (Table 5). In Pawaingyoe, the highest values of seed cotton yield and all of yield components were observed in $\mathrm{T} 2$ and the lowest ones were in $\mathrm{T} 1$ and T6. The maximum yield $\left(2364 \mathrm{~kg} \mathrm{ha}^{-1}\right)$ produced by $\mathrm{T} 2$ was not significantly different from the yields of T3, T4 and T5. The treatment T2 showed $71.69 \%$ higher seed cotton yield over T1. When the maximum potential of yield was achieved, the higher $\mathrm{N}$ rates caused a decrease in yield. According to this result, there was distinct response to $\mathrm{N}$ at T2 $\left(60 \mathrm{~kg} \mathrm{~N} \mathrm{ha}^{-1}\right)$ treatment in Pawaingyoe, and it may be assumed that further additional $\mathrm{N}$ rates were not needed to increase seed cotton yield. These results are supported by [22] who reported that $\mathrm{N}$ influenced seed cotton yield and decrease in seed cotton yield was recorded when $\mathrm{N}$ was applied above the optimum level. In Kokkokhahla, although the values of number of bolls plant ${ }^{-1}$, individual boll weight, boll weight plant ${ }^{-1}$ and seed cotton yield of $\mathrm{T} 4$ were the highest, they were not statistically differed from those of T3 through T6. The maximum seed cotton yield (1976 kg ha-1) of T4 was followed by $\left(1787 \mathrm{~kg} \mathrm{ha}^{-1}\right)$ of T3 which achieved $90 \%$ of the maximum. This clearly indicated that the effect of $\mathrm{N}$ fertilizer had positive effect on the yield components and over dose of $\mathrm{N}$ rate may decrease them. These results are in line with the findings reported by [23], who has concluded that $\mathrm{N}$ fertilization increase individual boll weight and seed cotton yield. According to the law of diminishing returns, when a nutrient is deficient, the first nutrient increment results in a large yield increase. The next increment may also give an increase, but not as proportionately large as the first and no further response to additional nutrients are realized.

Table 5. Mean comparison of yield and yield components of cotton as affected by $\mathrm{N}$ fertilization in Pawaingyoe and Kokkokhahla, 2019.

\begin{tabular}{|c|c|c|c|c|c|c|c|c|c|c|}
\hline \multirow{2}{*}{ Treatments } & \multicolumn{2}{|c|}{ No. of bolls plant ${ }^{-1}$} & \multicolumn{2}{|c|}{$\begin{array}{l}\text { Individual boll } \\
\text { weight (g) }\end{array}$} & \multicolumn{2}{|c|}{$\begin{array}{l}1000 \text { Seed } \\
\text { weight }(\mathrm{g})\end{array}$} & \multicolumn{2}{|c|}{$\begin{array}{c}\text { Boll weight } \\
\text { plant }^{-1}\left(\text { g plant }^{-1}\right)\end{array}$} & \multicolumn{2}{|c|}{ Yield $\left(\mathrm{kg} \mathrm{ha}^{-1}\right)$} \\
\hline & Pawaingyo & okkokhah & awaingyo & okkokhal & Pawaingyoe & cokkokhahl & awaingyo & cokkokhah & awaingyc & okkokhahla \\
\hline $\mathrm{T} 1$ & $15.69 \mathrm{c}$ & $12.34 \mathrm{c}$ & $3.98 \mathrm{~b}$ & $3.80 \mathrm{c}$ & $96.75 c$ & $98.50 \mathrm{c}$ & $48.67 \mathrm{c}$ & $39.87 \mathrm{c}$ & $1386 c$ & $1088 \mathrm{c}$ \\
\hline $\mathrm{T} 2$ & $25.02 \mathrm{a}$ & $16.85 b$ & $4.84 \mathrm{a}$ & $4.03 \mathrm{bc}$ & $114.75 a$ & $102.00 \mathrm{bc}$ & $83.56 \mathrm{a}$ & $50.78 \mathrm{bc}$ & $2364 a$ & $1529 b$ \\
\hline T3 & $22.61 \mathrm{ab}$ & $19.08 \mathrm{ab}$ & $4.22 \mathrm{~b}$ & $4.20 \mathrm{abc}$ & $110.00 \mathrm{ab}$ & $103 \mathrm{abc}$ & $74.67 \mathrm{ab}$ & $61.96 \mathrm{ab}$ & $2128 \mathrm{ab}$ & $1787 \mathrm{ab}$ \\
\hline $\mathrm{T} 4$ & $20.92 \mathrm{ab}$ & $21.16 \mathrm{a}$ & $4.42 \mathrm{ab}$ & $4.53 \mathrm{a}$ & $102.50 \mathrm{bc}$ & $107.5 \mathrm{ab}$ & $73.23 \mathrm{ab}$ & $71.47 \mathrm{a}$ & $2025 \mathrm{ab}$ & $1976 a$ \\
\hline T5 & $21.92 \mathrm{ab}$ & $19.52 \mathrm{ab}$ & $4.40 \mathrm{ab}$ & $4.08 \mathrm{bc}$ & $103.50 \mathrm{abc}$ & $110.00 \mathrm{a}$ & 72.71ab & $66.03 a$ & $2011 \mathrm{ab}$ & $1819 \mathrm{ab}$ \\
\hline T6 & $19.01 b c$ & $19.17 \mathrm{ab}$ & $4.17 \mathrm{~b}$ & $4.38 \mathrm{ab}$ & $102.00 \mathrm{bc}$ & $103.5 \mathrm{abc}$ & $63.72 b c$ & $64.48 \mathrm{ab}$ & $1772 b c$ & $1795 \mathrm{ab}$ \\
\hline $\mathrm{LSD}_{0.05}$ & 4.3 & 2.99 & 0.5 & 0.41 & 11.33 & 7.01 & 17.97 & 13.95 & 516.3 & 382.27 \\
\hline $\operatorname{Pr}>F$ & ** & $* *$ & * & * & * & * & * & $* *$ & * & $* *$ \\
\hline CV\% & 13.68 & 11.04 & 7.71 & 6.47 & 7.17 & 4.47 & 17.17 & 15.67 & 17.59 & 15.23 \\
\hline
\end{tabular}

Means followed by the same letter in each column are not significantly different at $5 \% \mathrm{LSD}$; ${ }^{*}=$ significant at $1 \%$ level; ${ }^{*}=$ significant at $5 \%$ level; ns $=$ non-significant. 


\subsection{Water Use Efficiency (WUE $\mathrm{kg} \mathrm{ha}^{-1} \mathrm{~mm}^{-1}$ )}

Generally, WUE values observed in the Pawaingyoe (sandy loam, high PAWC) were higher than those observed in Kokkokhahla (clay loam, low PAWC) (Figure 7). The higher WUE $45 \%$ to $64 \%$ in crops grown on clayey than sandy soils [24]. In a different study, [25] also reported 25\% higher WUE for rice grown on clayey than sandy loam soils. The highly significant difference in WUE was observed among the treatments in both sites and the maximum WUE (6.04 $\left.\mathrm{kg} \mathrm{ha}^{-1} \mathrm{~mm}^{-1}\right)$ was recorded from T2 in Pawaingyoe and $\left(3.80 \mathrm{~kg} \mathrm{ha}^{-1} \mathrm{~mm}^{-1}\right)$ was obtained from T4 in Kokkokhahla. WUE for both sites were the lowest at $\mathrm{N}$ omission treatments $\left(3.54 \mathrm{~kg} \mathrm{ha}^{-1} \mathrm{~mm}^{-1}\right.$ in Pawingyoe and $2.09 \mathrm{~kg} \mathrm{ha}^{-1} \mathrm{~mm}^{-1}$ in Kokokhahla) and increased for the $\mathrm{N}$ fertilized treatments. According to [26], without $\mathrm{N}$ application WUE of wheat was low and increased with fertilization. Application of fertilizer may increase the total water use by a small amount, either by increasing the depth of water extraction, or the amount extracted from specific soil layers or both [27].

\subsection{Agronomic Nitrogen Use Efficiency (NUE)}

The agronomic efficiency of NUE used by cotton in Pawaingyoe and Kokkokhahla, is shown in Figure 8 that differed from location to location and treatment to treatment. It was observed that NUE gradually decreased with increasing $\mathrm{N}$ rate in Pawaingyoe. The low NUE may be attributed to fertilizer overuse and high nutrient loss [28]. Owing to the law of diminishing returns, the yield per unit $\mathrm{N}$ supply declines with increasing $\mathrm{N}$ supply [29]. The highest values of NUE (16.31) and (7.76) were obtained from T2 $\left(60 \mathrm{~kg} \mathrm{~N} \mathrm{ha}^{-1}\right)$ at Pawaingyoe and T3 (90 $\mathrm{kg} \mathrm{N} \mathrm{ha}^{-1}$ ) at Kokkokhahla, respectively. This trend would show that loss of $\mathrm{N}$ increased at higher dose which must be managed with approaching $\mathrm{N}$ management strategies. According to [30], application of the required amount of $\mathrm{N}$ to crop increase NUE.

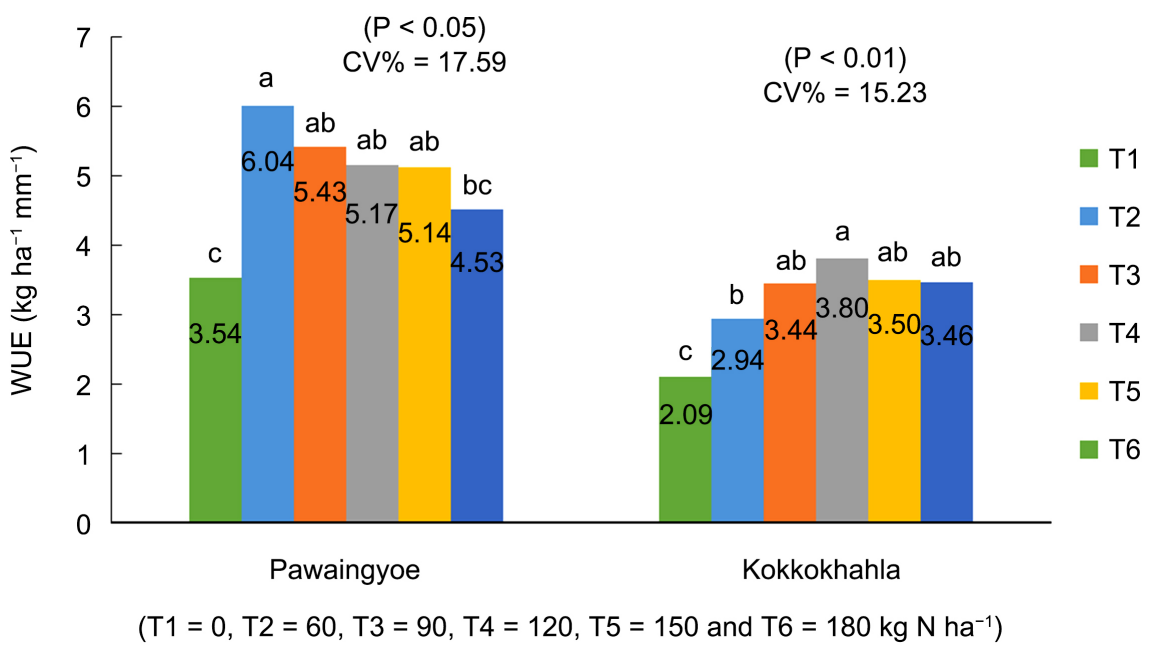

Figure 7. Effect of $\mathrm{N}$ fertilization on water use efficiency (WUE) in Pawaingyoe and Kokkokhahla. 


\subsection{Benefit Cost Ratio (BCR)}

The economic analysis is necessary from farmer's point of view. The benefit cost ratio (BCR) of various treatments used in the experiments is given in Figure 9. In Pawaingyoe, the highest BCR (10.85) was obtained from T2 $\left(60 \mathrm{~kg} \mathrm{~N} \mathrm{ha}^{-1}\right)$ that decreased with the increasing rate of N. In Kokkokhahla, the highest BCR (3.39) was obtained from the $\mathrm{T} 4\left(120 \mathrm{~kg} \mathrm{~N} \mathrm{ha}^{-1}\right)$ followed by $\mathrm{T} 3\left(90 \mathrm{~kg} \mathrm{~N} \mathrm{ha}^{-1}\right)$ with BCR (3.12); that decreased with decreasing or increasing rate of $\mathrm{N}$. The goal of fertilizer programs for cotton should be to achieve maximum economic return for the fertilizer investment even though this may not necessary coincide with maximum yield, and it may change with time and with location [31]. Highest return and net profit values observed in the T2 and T4 treatments of Pawaingyoe and Kokkokhahla can be attributed to the increases in seed cotton yield produced per unit area under these treatments.

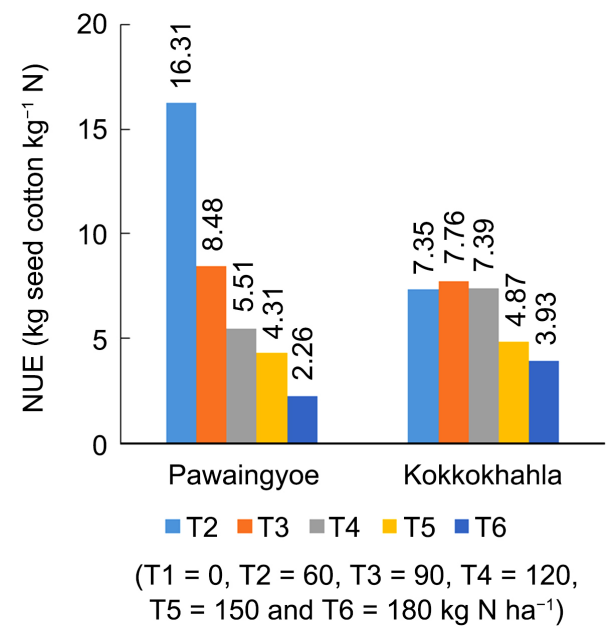

Figure 8. Effect of $\mathrm{N}$ fertilization on NUE in Pawaingyoe and Kokkokhahla.

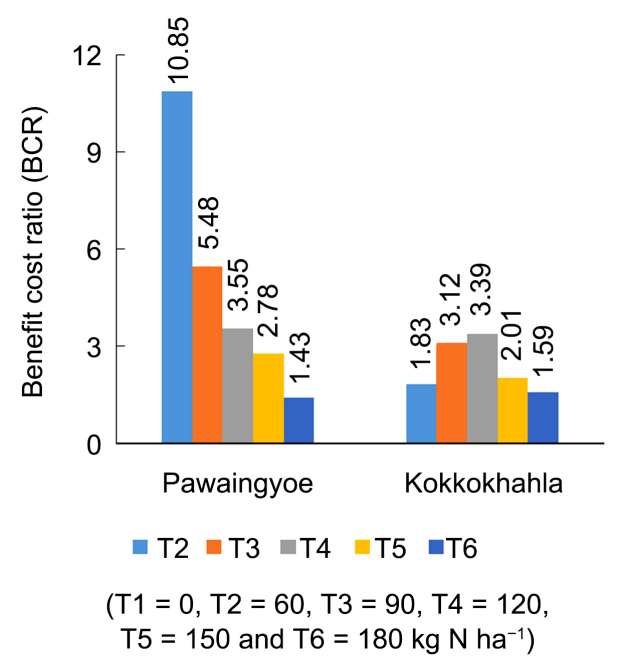

Figure 9. Benefit cost ratio of treatments used in Pawaingyoe and Kokkokhahla. 


\subsection{Discussion}

Soil water and nutrients have great interactions that may gain either positive or negative effects on crop production. In $\mathrm{CDZ}$, the effect of nutrients and that of water are often limited to each other. Remarkable variations in precipitation from year to year significantly influence soil water and nutrient status, and so do the nutrient input effect. Generally, nutrient input may obtain a good harvest in wet year while a poor harvest in dry year. The monthly average precipitations during 2019 were higher than 10 years average precipitation and the strong response to $\mathrm{N}$ was observed in both sites. The growing season rainfall in Kokkokhahla was higher than Pawaingyoe. However, Pawaingyoe had higher PAWC and thus larger water and $\mathrm{N}$ buffers than Kokkokhahla. High PAWC can provide a large buffer that moderates the impact of within-season variability in rainfall on yield [32]. The efficiency of $\mathrm{N}$ fertilizer used depends not only on the precipitation received by the crop but also on PAWC. Kokkokhahla (lower PAWC) has sandy loam texture and cotton grown on this soil was more responsive to $\mathrm{N}$ than clay loam texture soil of Pawaingyoe (higher PAWC), probably because organic $\mathrm{N}$ reserves are lower, the soil is more often dry, and $\mathrm{NO}_{3}^{-}-\mathrm{N}$ cannot be held in the profile against leaching. Leaching of $\mathrm{NO}_{3}^{-}-\mathrm{N}$ should be considered in $\mathrm{N}$ fertilizer management. The residual soil $\mathrm{NO}_{3}^{-}-\mathrm{N}$ concentration of Pawaingyoe (clay loam, higher OC\%) was higher than that of Kokkokhahla (sandy loam, lower OC\%). In Pawaingyoe, higher amount of residual soil $\mathrm{NO}_{3}^{-}-\mathrm{N}$ was retained in near surface depth while in Kokkokhahla most of the residual soil $\mathrm{NO}_{3}^{-}-\mathrm{N}$ leached to deeper depth. Soils with low PAWC are typically sandier and crops grown on these soils are more responsive to $\mathrm{N}$ than finer textured soils [33]. In this study, Pawaingyoe (high PAWC) was found to be better in terms of growth, yield, NUE and WUE than Kokkokhahla (low PAWC), as high PAWC can lead to more water use and the availability of water to crops.

\section{Conclusion}

The experimental year 2019 was a high rainfall year and under this wet condition, maximum seed cotton yield, WUE, NUE and BCR were found in T2 and it may be assumed that $\mathrm{T} 2\left(60 \mathrm{~kg} \mathrm{~N} \mathrm{ha}^{-1}\right)$ is the most suitable rate for Pawaingyoe. In Kokkokhahla, the maximum seed cotton yield, WUE and BCR were obtained in T4 $\left(120 \mathrm{~kg} \mathrm{~N} \mathrm{ha}^{-1}\right)$. However, the maximum NUE was observed in T3 $(90 \mathrm{~kg}$ $\mathrm{N} \mathrm{ha}{ }^{-1}$ ). Moreover, T3 gave $90.43 \%$ of maximum yield and low residual $\mathrm{NO}_{3}^{-}-\mathrm{N}$ than T4. Thus, the most suitable rate for this site may be within the range between T3 and T4 (90 to $120 \mathrm{~kg} \mathrm{~N} \mathrm{ha}^{-1}$ ). Further investigations will be necessary to understand the response of $\mathrm{N}$ fertilization on seed cotton yield of different cultivars, NUE and WUE under different climatic condition of this PAWC sites.

\section{Acknowledgements}

We gratefully acknowledge to Myanmar Awba Group and ACIAR Project (LWR 
2014/075) for their partial financial support for conducting this research work.

\section{Conflicts of Interest}

The authors declare no conflicts of interest regarding the publication of this paper.

\section{References}

[1] Myanmar National Census Report (MNCR) (2014) The 2014 Myanmar Population and Housing Census: Mandalay Region, Sagaing Region and Magway Region. Department of Population, Ministry of Immigration and Population, Nay Pyi Taw.

[2] Japan International Cooperation Agency (JICA) (2010) The Development Study on Sustainable Agricultural and Rural Development for Poverty Reduction Programme in the Central Dry Zone of the Union of Myanmar. Sanyu Consultants Inc., Tokyo.

[3] Wang, B., Liu, D., Asseng, S., Macadam, I. and Yu, Q. (2017) Modelling Wheat Yield Change under $\mathrm{CO}_{2}$ Increase, Heat and Water Stress in Relation to Plant Available Water Capacity in Eastern Australia. European Journal of Agronomy, 90, 152-161. https://doi.org/10.1016/j.eja.2017.08.005

[4] Ritchie, J. (1981) Water Dynamics in the Soil-Plant-Atmosphere System. Plant and Soil, 58, 81-96. https://doi.org/10.1007/978-94-015-0861-2_4

[5] Dalgliesh, N.P. and Foale, M.A. (1998) Soil Matters (Monitoring Soil Water and Nutrients in Drying Farming). Agricultural Production Systems Research Unit, CSIRO, Toowoomba.

[6] Pye Tin (2003) Myanmar's Perspective on Increasing Cotton Production in Light of Global Production Changes. Institute of Development Economics, Chiba.

[7] Prasad, R. and Power, J.F. (1995) Nitrification Inhibitors for Agriculture, Health and Environment. Advance Agronomy, 54, 233-281. https://doi.org/10.1016/S0065-2113(08)60901-3

[8] Singh, J. and Mannikar, N.D. (1988) Studies on Nitrogen Transformation in Vertisol as Influenced by Different N Carriers and Its Effect on Growth, Yield and Uptake in Rainfed Cotton. In: Classification, Management and Use Potential of Swell Shrink Soils, Oxford IBH, New Delhi, 207-210.

[9] Hou, Z., Li, P., Li, B., Gong, Z. and Wang, Y. (2007) Effects of Fertigation Scheme on N Uptake and N Use Efficiency in Cotton. Plant Soil, 290, 115-126. https://doi.org/10.1007/s11104-006-9140-1

[10] Blaise, D., Venugopalan, M.V., Singh, J.V. and Raju, A.R. (2013) Fertilizer Best Management Practices in Cotton. Indian Journal of Fertilisers, 9, 110-119.

[11] Mitchell, C.C. (2010) Research-Based Soil Testing and Recommendations for Cotton on Coastal Plain Soils. Southern Cooperative Series Bulletin No. 410.

[12] Di Paolo, E. and Rinaldi, M. (2008) Yield Response of Corn to Irrigation and Nitrogen Fertilization in a Mediterranean Environment. Field Crop Research, 105, 202-210. https://doi.org/10.1016/j.fcr.2007.10.004

[13] Myanmar Information Management Unit (MIMU)

(a)http://themimu.info/special-interest-region/dry-zone

(b)https://themimu.info/sites/themimu.info/files/documents/VT\%20Map_Pyawbwe \%20Tsp_MDY_MIMU352v01_13Nov10_A4.pdf

[14] Gregory, P.J. (1991) Concept of Water Use Efficiency. In: Harris, H.C., Cooper, P.J.M. and Pala, M., Eds., Soil and Crop Management for the Improved Water Use 
Efficiency in Rainfed Areas, ICARDA, Beirut, 9-20.

[15] Novoa, R. and Loomis, R. (1981) Nitrogen and Plant Production. In: Soil Water and Nitrogen in Mediterranean- Type Environments, Springer, Berlin, 177-204.

https://doi.org/10.1007/978-94-015-0861-2_7

[16] Amooh, M.K. and Bonsu, M. (2015) Effects of Soil Texture and Organic Matter on Evaporative Loss of Soil Moisture. Journal of Global Agriculture and Ecology, 3, 152-161.

[17] McCarthy, J.J., Canziani, O.F., Leary, N.A., Dokken, D.J. and White, K.S. (2001) Climate Change: Impacts, Adaptation, and Vulnerability: Contribution of Working Group II to the Third Assessment Report of the Intergovernmental Panel on Climate Change (Vol. 2). Cambridge University Press, Cambridge.

[18] Fan, J., Hao, M. and Malhi, S.S. (2010) Accumulation of Nitrates in the Soil Profile and Its Implications for the Environment under Dry Land Agriculture, China. A Review. Canadian Journal of Soil Science, 90, 429-440.

https://doi.org/10.4141/CJSS09105

[19] Aronsson, H., Torstensson, G. and Bergström, L. (2007) Leaching and Crop Uptake of N, P and K from a Clay Soil with Organic and Conventional Cropping Systems. Soil Use and Management, 23, 71-81. https://doi.org/10.1111/j.1475-2743.2006.00067.x

[20] https://youtu.be/hjtxft4nPjg

[21] Mukand, S., Brarand, Z.S. and Sharma, P.K. (1989) Growth and Yield of Cotton in Relation to Nitrogen Rates and Scheduling of Last Irrigation. Journal of Research, Punjab Agricultural University, 26, 14-18.

[22] Bell, P.F., Boquet, D.J., Millhollon, E., Moore, S., Ebelhar, W., Mitchell, C.C., et al. (2003) Relationships between Leaf Blade Nitrogen and Relative Seed Cotton Yields. Crop Science, 43, L1367-L1374. https://doi.org/10.2135/cropsci2003.1367

[23] Khan, M.D., Hassan, M., Khan, M.A. and Ibrahim, M. (1993) Effect of Different Doses and Times of Application of $\mathrm{N}$ on Cotton Variety S-12 Yield and Yield Components. The Pakistan Cottons, 37, 91-96.

[24] Ismail, S. and Ozawa, K. (2007) Improvement of Crop Yield, Soil Moisture Distribution and Water Use Efficiency in Sandy Soils by Clay Application. Applied Clay Science, 37, 81-89. https://doi.org/10.1016/j.clay.2006.12.005

[25] Dou, F., Soriano, J., Tabien, R. and Chen, K. (2016) Soil Texture and Cultivar Effects on Rice (Oryza sativa L.) Grain Yield, Yield Components and Water Productivity in Three Water Regimes. PLoS ONE, 11, e0150549. https://doi.org/10.1371/journal.pone.0150549

[26] Dang, T.H. (1999) Effects of Fertilization on Water Use Efficiency of Winter Wheat in Arid Highland. Eco-Agriculture Research, 7, 28-31. (In Chinese)

[27] Brown, P.L. (1971) Water Use and Soil Water Depletion by Dryland Winter Wheat as Affected by Nitrogen Fertilization. Agronomy Journal, 63, 43-46. https://doi.org/10.2134/agronj1971.00021962006300010015x

[28] Fan, M., Shen, J., Yuan, L., Jiang, R., Chen, X., Davies, W.J. and Zhang, F. (2012) Improving Crop Productivity and Resource Use Efficiency to Ensure Food Security and Environmental Quality in China. Journal of Experimental Botany, 63, 13-24. https://doi.org/10.1093/jxb/err248

[29] Gastal, F., Lemaire, G., Durand, J.L. and Louarn, G. (2015) Quantifying Crop Responses to Nitrogen and Avenues to Improve Nitrogen-Use Efficiency. In: Crop Physiology: Applications for Genetic Improvement and Agronomy, Academic Press, San Diego, 161-206. https://doi.org/10.1016/B978-0-12-417104-6.00008-X 
[30] Keeney, D.R. (1982) Nitrogen Management for Maximum Efficiency and Minimum Pollution Farmed Soils, Fertilizer, Agro-Ecosystems. American Society of Agronomy, Madison.

[31] Kerby, T.A. and Adams, F. (1985) Potassium Nutrition of Cotton. In: Potassium in Agriculture, American Society of Agronomy, Madison, 843-860. https://doi.org/10.2134/1985.potassium.c36

[32] Wang, E., Cresswell, H., Xu, J. and Jiang, Q. (2009) Capacity of Soils to Buffer Impact of Climate Variability and Value of Seasonal Forecasts. Agricultural and Forest Meteorology, 149, 38-50. https://doi.org/10.1016/j.agrformet.2008.07.001

[33] Oliver, Y.M. and Robertson, M.J. (2009) Quantifying the Benefits of Accounting for Yield Potential in Spatially and Seasonally Responsive Nutrient Management in a Mediterranean Climate. Soil Research, 47, 114-126.

https://doi.org/10.1071/SR08099 